$\begin{array}{ll} & \text { Etnográfica } \\ \text { etnográfica } & \text { Revista do Centro em Rede de Investigação em }\end{array}$

Antropologia

vol. $20(3) \mid 2016$

Vol. 20 (3)

\title{
Challenging approaches and crossovers in anthropology and conservation in Guinea-Bissau
}

Desafiando abordagens e cruzamentos na antropologia e na conservação na Guiné-Bissau

\section{Amélia Frazão-Moreira}

\section{(2) OpenEdition}

\section{Journals}

Electronic version

URL: https://journals.openedition.org/etnografica/4762

DOI: 10.4000/etnografica.4762

ISSN: 2182-2891

\section{Publisher}

Centro em Rede de Investigação em Antropologia

\section{Printed version}

Date of publication: 1 October 2016

Number of pages: 663-667

ISSN: 0873-6561

\section{Electronic reference}

Amélia Frazão-Moreira, "Challenging approaches and crossovers in anthropology and conservation in Guinea-Bissau", Etnográfica [Online], vol. 20 (3) | 2016, Online since 28 November 2016, connection on 10 February 2022. URL: http://journals.openedition.org/etnografica/4762 ; DOI: https://doi.org/ 10.4000/etnografica.4762

\section{(c) (7) (8)}

Etnográfica is licensed under a Creative Commons Attribution-NonCommercial 4.0 International License. 


\title{
Challenging approaches and crossovers in anthropology and conservation in Guinea-Bissau
}

\begin{abstract}
Amélia Frazão-Moreira
This communication presents research conducted according to the theoretical viewpoint held passionately by Cláudia Sousa: the need for an interdisciplinary perspective between anthropology, primatology and conservation. Only then can a holistic understanding of human and chimpanzee interactions be achieved that includes local knowledge, and involves local populations in biodiversity conservation.

KEYWORDS: environmental anthropology, conservation, local ecological knowledge, human and nonhuman primate interaction, interdisciplinary research.

Desafiando abordagens e cruzamentos na antropologia e na conservação na Guiné-Bissau - Esta comunicação apresenta estudos realizados de acordo com o posicionamento teórico defendido de forma empenhada por Cláudia Sousa: a necessidade de uma perspetiva interdisciplinar entre a antropologia, a primatologia e a conservação. Só assim uma compreensão holística da interação entre humanos e chimpanzés que inclua o conhecimento local e o envolvimento das populações locais na conservação da biodiversidade poderá ser alcançada.
\end{abstract}

PALAVRAS-CHAVE: antropologia ambiental, conservação, conhecimento ecológico local, interação entre primatas humanos e não humanos, investigação interdisciplinar.

FRAZÃO-MOREIRA, Amélia (amoreira@fcsh.unl.pt) - CRIA; Faculdade de Ciências Sociais e Humanas, Universidade Nova de Lisboa (FCSH/Nova), Portugal.

DOES COMBINING ANTHROPOLOGY AND CONSERVATION ENTAIL AN anthropology which is solely concerned with the wildlife or should it contemplate an approach in which people matter, and local reality and human expectations are taken into account?

An anthropological approach allows for a critical deconstruction of the processes in conservation (e.g., Büscher et al. 2012), and even for the concept of biodiversity itself (Escobar 1998). However, "whether the problem of biodiversity loss was cast in a straight and narrow economic mode or in a more encompassing biocentric mode" (Nazarea 2006: 319), the result was the commitment of the scientific community and policy makers. In this domain, as in all others for that matter, anthropology cannot distance itself from debates and discussions, and certainly not from the field of intervention. 
Thus, two assumptions emerge:

- applied environmental anthropology allows us to capture humans' practical engagement with the world;

- interdisciplinary frameworks allow for a more holistic view of inter-species (humans and nonhumans) relationships.

Cross-disciplinary research requires a set of approximations and interconnections of languages, perspectives, and methodologies and, rather more difficultly, the overcoming of perspectives rooted in paradigms that in their origin are distanced, or even contradictory.

The research conducted by Cláudia and I, as part of larger teams, interconnected often disparate fields, combining themes in social anthropology with primatology applied to the conservation of chimpanzees (Pan troglodytes verus) in Guinea-Bissau.

A more contemporary perspective towards conservation assumes the integration of, and respect towards, local peoples' ecological knowledge, through incorporating local processes of use and management of natural resources into conservation strategies. For this to be achieved, it is necessary to understand relationships between the local population and wildlife, in this case the chimpanzee, as well as their relationship with the forest. In this sense, the first "crossover" was to understand what local people think about chimpanzees. The results of two case studies undertaken in Cufada Natural Park and Cantanhez National Park ${ }^{1}$ point towards a local anthropomorphic perception of the chimpanzees, expressed in the sentence "dari i pekador" (the chimpanzee is human), associated to a narrative of a mythological nature that explains similarities in the physical appearance and in the behaviour of humans and chimpanzees (Sousa and Frazão-Moreira 2010; Sousa et al. 2014). The chimpanzee is a food taboo in all ethnic groups (Costa et al. 2013; Sousa and Frazão-Moreira 2010) and has also become a "flagship species" (Noss 1990; Walpole and Leader-Williams 2002). This local "positive perception" seems to coincide with the image that conservationists cultivate, very clearly expressed in state organisations and NGOs' documents. The chimpanzee is nowadays a "brand", performing a strategic economic role (ecotourism), in a process of "commoditization of nature".

This takes us to a first challenge: to understand the complexity of the relationship between humans and the other species, as this relationship goes beyond the narrative. The positive image of the chimpanzees in the local narratives and projected by conservationists can be contradictory with the survival needs 
and scarcity of resources which lead to changes in human engagement with the forest and the chimpanzees. The urgent need for preservation is not always shared by the local populations, and research demonstrates a local belief that the forest and fauna are infinite (Pais 2005; Sousa 2009). On the other hand, the acceptance of conservation directives and discourses is performed differently by social actors, and can be performed differently by the same social actor in different situations according to survival strategies. The engagement of some stakeholders in the conservation process leads to reconfigurations of social and economic organization.

The second crossover concerns local ecological knowledge and its relationship with scientific knowledge. In order to gather information on the social variability in local knowledge and perceptions of nonhuman animals, we carried out structured interviews to 136 subjects (diversified in terms of ethnic group, age, gender, levels attained at official and Islamic school, and migration experience) and a free pile sorting task. The results show that local knowledge is detailed and does not vary significantly from scientific knowledge (for example in what concerns a chimpanzee's diet, mating behaviour, and habitat preference). Results also demonstrate that it is important to consider the specificities of different human populations (in this case Cufada NP versus Cantanhez NP) and also to consider the heterogeneity of local populations as gender and age variability influenced perceptions of chimpanzees. This is another challenge: combining local and the scientific knowledge, whilst respecting social variability in ways of thinking and engagement with other species.

The third crossover between anthropology and conservation concerns local natural resource and territory use and management.

In the two studies in Cantanhez National Park ${ }^{2}$ we mapped the ecozones and overlaid the chimpanzees' habitat. The features of the landscape essentially resemble forest fragments dotted with more human-modified areas. As local people employ a slash-and-burn system, these openings are changeable, whereby the landscape is reconfigured from year to year. This variability is the most noticeable feature in the territory's social configuration, and determines its occupation by chimpanzees.

Tsing notes that "The forest is a terrain of personal biography and community history. [...] Yet almost all scholarship and policy continues to portray forests as wild, natural spaces outside society. If forests were recognized as

2 The first study and data gathering was done within the previously mentioned project and the cartography in the project “'Social geography': oral history, land use and knowledge about non-human species in Guinea-Bissau” (CRIA), coordination: Amélia Frazão-Moreira and Cláudia Sousa; the second study was done within the project "Where humans and chimpanzees meet: assessing sympatry throughout Africa using a multi-tiered approach” (FCT/PTDC/CS-ANT/121124/2010), coordination: Kimberley J. Hockings. 
social, the predominant forms of both resource exploitation and conservation that have been imposed would seem very odd indeed" (2005: 7).

Hence, the final challenge centres in how to connect the social and resilient reconfiguration of humanized ecological systems to conservation models and expectations?

The challenge can only be answered by those who share the view expressed by Ingold:

"Our hostility, however, is to scientism. Science and scientism are quite different. The former is a rich patchwork of knowledge which comes in an astonishing variety of different forms. The latter is a doctrine, or a system of beliefs, founded on the assertion that scientific knowledge takes only one form, and that this form has an unrivalled and universal claim to truth. [...] Thus within the discipline of anthropology itself the debate is not between biological anthropologists committed to science and social anthropologists who reject it; it is rather between the cult of scientism and those who are prepared to adopt a more open-ended and less complacent approach to scientific inquiry" (2013: 14).

The legacy of Cláudia bears witness to how much she shared this idea.

\section{REFERENCES}

BÜSCHER, Bram, et al., 2012, "Towards a synthesized critique of neoliberal biodiversity conservation”, Capitalism Nature Socialism, 23 (2): 4-30.

COSTA, Susana, et al., 2013, "The good, the bad and the ugly: perceptions of wildlife in Tombali (Guinea-Bissau, West Africa)”, Journal of Primatology, 2 (1): \# 110.

ESCOBAR, Arturo, 1998, "Whose knowledge, whose nature? Biodiversity, conservation, and the political ecology of social movements", Journal of Political Ecology, 5: 53-82.

INGOLD, Tim, 2013, "Prospect", in Tim Ingold and Gisli Palsson (eds.), Biosocial Becomings: Integrating Social and Biological Anthropology. Cambridge, Cambridge University Press, $1-21$.

NAZAREA, Virginia, 2006, "Local knowledge and memory in biodiversity conservation", Annual Review of Anthropology, 35: 317-335.

NOSS, Reed, 1990, "Indicators for monitoring biodiversity: a hierarchical approach", Conservation Biology, 4 (4): 355-364.

PAIS, Verónica, 2005, "Nós e eles: contributo para o estudo da interacção entre primatas não humanos e humanos nas regiões administrativas de Quinara e Tombali - República 
da Guiné-Bissau", research seminar held in the scope of the degree in Anthropology, Lisbon, ISCSP.

SOUSA, Cláudia, and Amélia FRAZÃO-MOREIRA, 2010, "Etnoprimatologia ao serviço da conservação na Guiné-Bissau: o chimpanzé como exemplo”, in Ângelo Giuseppe Chaves Alves, Francisco José Bezerra Souto and Nivaldo Peroni (eds.), Etnoecologia em Perspectiva: Natureza, Cultura e Conservação. Recife, NUPEEA, 187-200.

SOUSA, Fernando Miguel, 2009, Densidade de Pan troglodytes verus e Uso de Recursos Naturais pela População Local (Gadamael, República da Guiné-Bissau). Lisbon, FCUL, M.Sc. thesis.

SOUSA, Joana, et al., 2014, "Local knowledge and perceptions of chimpanzees in Cantanhez National Park, Guinea-Bissau", American Journal of Primatology, 76: 122-134.

TSING, Anna, 2005, Friction: An Ethnography of Global Connections. Princeton, Princeton University Press.

WALPOLE, Matthew J., and Nigel LEADER-WILlIAMS, 2002, "Tourism and flagship species in conservation", Biodiversity and Conservation, 11 (3): 543-547. 